\title{
Wnt signaling in cancer stem cells and colon cancer
}

\section{metastasis [version 1; peer review: 3 approved]}

\author{
Sayon Basu*, Gal Haase*, Avri Ben-Ze'ev \\ Department of Molecular Cell Biology, Weizmann Institute of Science, Rehovot, Israel \\ * Equal contributors
}

V1 First published: 19 Apr 2016, 5(F1000 Faculty Rev):699

https://doi.org/10.12688/f1000research.7579.1

Latest published: 19 Apr 2016, 5(F1000 Faculty Rev):699

https://doi.org/10.12688/f1000research.7579.1

\section{Abstract}

Overactivation of Wnt signaling is a hallmark of colorectal cancer (CRC). The Wnt pathway is a key regulator of both the early and the later, more invasive, stages of CRC development. In the normal intestine and colon, Wnt signaling controls the homeostasis of intestinal stem cells (ISCs) that fuel, via proliferation, upward movement of progeny cells from the crypt bottom toward the villus and differentiation into all cell types that constitute the intestine. Studies in recent years suggested that cancer stem cells (CSCs), similar to ISCs of the crypts, consist of a small subpopulation of the tumor and are responsible for the initiation and progression of the disease. Although various ISC signature genes were also identified as CRC markers and some of these genes were even demonstrated to have a direct functional role in CRC development, the origin of CSCs and their contribution to cancer progression is still debated. Here, we describe studies supporting a relationship between Wnt-regulated CSCs and the progression of CRC.

\section{Keywords}

Wnt, colorectal cancer, intestinal stem cells, cancer stem cells , $\beta$ catenin , Lgr5

\section{Open Peer Review

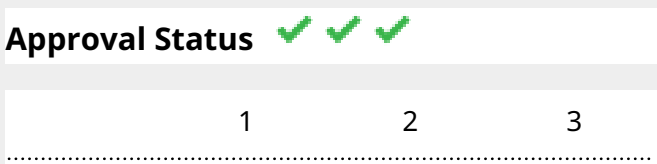 \\ version 1 \\ 19 Apr 2016 \\ Faculty Reviews are review articles written by the prestigious Members of Faculty Opinions. The articles are commissioned and peer reviewed before publication to ensure that the final, published version is comprehensive and accessible. The reviewers who approved the final version are listed with their names and affiliations.}

1. Jan Paul Medema, Academic Medical Center, Amsterdam, The Netherlands

2. Takeshi Sakurai, Kyoto University Graduate School of Medicine, Kyoto, Japan

3. Hans Clevers, Hubrecht Institute and University Medical Center, Utrecht, The Netherlands

Marc van de Wetering, Royal Netherlands Academy of Arts and Sciences, Utrecht,, The Netherlands

Any comments on the article can be found at the end of the article. 
Corresponding author: Avri Ben-Ze'ev (avri.ben-zeev@weizmann.ac.il)

Competing interests: The authors declare that they have no competing interests.

Grant information: Studies from the authors' laboratory were supported by grants from the Israel Science Foundation (ISF) and the Israel Cancer Research Fund (ICRF).

Copyright: @ 2016 Basu S et al. This is an open access article distributed under the terms of the Creative Commons Attribution License, which permits unrestricted use, distribution, and reproduction in any medium, provided the original work is properly cited.

How to cite this article: Basu S, Haase G and Ben-Ze'ev A. Wnt signaling in cancer stem cells and colon cancer metastasis [version

1; peer review: 3 approved] F1000Research 2016, 5(F1000 Faculty Rev):699 https://doi.org/10.12688/f1000research.7579.1

First published: 19 Apr 2016, 5(F1000 Faculty Rev):699 https://doi.org/10.12688/f1000research.7579.1 


\section{Introduction}

Wnt signaling has emerged during evolution as a highly conserved signaling pathway that regulates tissue morphogenesis and regeneration (via stem cells) in various tissues of multicellular organisms $^{1}$. Hyperactivation of $\beta$-catenin-T cell factor (TCF)/ lymphoid enhancer factor (LEF)-regulated gene transcription (the end point of Wnt signaling) is a hallmark of colorectal cancer (CRC) development. $\beta$-catenin is also a key regulator of cell-cell adhesion, by linking the E-cadherin transmembrane adhesion receptor that binds neighboring epithelial cells to each other, to the actin-cytoskeleton $^{2}$. Therefore, activation of the Wnt pathway in CRC provides an attractive model for studying the links between tissue morphogenesis and cell adhesion and the disregulation of these processes during cancer progression.

The canonical Wnt pathway is also known as the Wnt- $\beta$-catenin pathway since $\beta$-catenin is a key transducer of the Wnt signal from the cytoplasm to the nucleus. In unstimulated cells, the free pool of $\beta$-catenin (the one not engaged in cadherin-mediated cell-cell adhesion) is phosphorylated by a complex of proteins that includes the scaffold molecule Axin and adenomatous polyposis coli (APC) and the kinases glycogen synthase kinase $3 \beta$ (GSK3 $\beta$ ) and casein kinase $1(\mathrm{CK} 1)^{1,2}$. After phosphorylation, $\beta$-catenin is targeted for proteolytic degradation by the proteasome. Wnt is secreted from cells as a lipid-modified molecule that acts in short-range signaling ${ }^{3,4}$ and stimulates signaling by binding of the Wnt ligands to the Frizzled transmembrane receptors and to the Lrp5/6 co-receptors. The cytoplasmic tail of Lrp becomes phosphorylated, inhibits GSK3 $\beta$, and associates with Axin. Wnt signaling is positively regulated by the secreted R-spondins that act to stabilize the Frizzled receptors against degradation by the Rnf43/Znrf3 ubiquitin ligases ${ }^{5,6}$. Activation of the Wnt pathway results in the disruption of the CK1-GSK3 $\beta$-Axin-APC- $\beta$-catenin complex, inhibition of GSK3$\beta$ activity, and the stabilization of $\beta$-catenin against degradation in the cytoplasm by the ubiquitin-proteasome pathway. The accumulation of $\beta$-catenin in the cytoplasm results in its nuclear translocation. In the nucleus, $\beta$-catenin binds to members of the TCF/LEF family of transcription factors and plays a role as a co-activator of target gene transcription ${ }^{7}$. In CRC, aberrant activation of the Wnt signaling pathway is a central oncogenic driver in $90 \%$ of patients, mostly resulting from mutations in the $A P C$ gene $^{8}$. Expression of genes by the aberrant transcriptional activity of the $\beta$-catenin-TCF complex contributes to both the initial stages of the disease and the later stages involving invasion and metastasis ${ }^{9}$. Here, we describe recent findings on the involvement of Wnt signaling in CRC progression and its relationship to the emerging role of cancer stem cells (CSCs) in CRC.

\section{Wnt signaling in intestinal stem cell homeostasis}

Intestinal epithelial cells display the highest turnover rate, and the entire intestinal epithelial lining in humans is replaced every 5 to 7 days $^{10}$. This rapid regeneration is fueled by the proliferation of stem cells at the base of the intestinal crypts of Lieberkühn and the upward migration and differentiation of stem cells that enables normal tissue homeostasis. The morphological separation of the stem cell compartment (the crypt where the cells proliferate) and the differentiated compartment (villus in the intestine, and the surface epithelium in the colon, where the cells interact with the gut environment) depends on a gradient of Wnt signaling. The strongest Wnt signaling is detected at the crypt base (where some cells display nuclear $\beta$-catenin localization) and gradually weakens toward the luminal side of the vertical crypt-villus axis ${ }^{11}$. Wnt signaling is necessary for the initial potentiation of intestinal stem cells (ISCs) as evident from studies in neonatal transgenic mice that lost TCF4 and thus fail to develop normal proliferative crypts ${ }^{12}$. Both crypt homeostasis and stem cell maintenance require active Wnt signaling since conditional activation of Wnt antagonists in transgenic mice leads to the progressive loss of intestinal crypts ${ }^{13-15}$. Similarly, conditional abrogation of Wnt signaling in cells at the crypt base, by deletion of either $\beta$-catenin ${ }^{16}$ or TCF $4{ }^{17}$, leads to the loss of proliferative crypts.

The intestinal crypt has long been recognized as the niche for proliferative, multipotent precursor cells of the intestine and colon, and the Wnt target gene Lgr5, a receptor for the Wnt agonist $\mathrm{R}$-spondin that enhances Wnt signaling, was identified as a marker for columnar crypt base stem cells ${ }^{18}$. Lineage-tracing experiments in transgenic mice revealed that $\mathrm{Lgr}^{+}$cells found in the crypt base are multipotent and capable of clonally repopulating the entire epithelial lining of the intestine and colon ${ }^{18}$. Gene expression and proteomic signature studies of $\mathrm{Lgr}^{+}$cells revealed several additional ISC markers, including Ascl2 and Sox ${ }^{19}$. The basic helix-loop-helix (bHLH) transcription factor Ascl2 is a major transcriptional regulator of genes associated with stemness in crypt cells and is a key ISC marker ${ }^{20}$. Similarly, the transcription factor Sox 9 is also expressed by stem cells in the intestinal and colonic crypt base and is necessary for the maintenance of ISCs ${ }^{21,22}$. Like Lgr5, Ascl2 and Sox9 are also Wnt target genes in ISCs. This points to the requirement for high Wnt signaling in the maintenance of the stem cell niche ${ }^{23}$.

Experiments tracking cell proliferation and migration in the intestine identified as putative stem cells, cells at position +4 ( 4 cells up from the crypt base) in the intestine. These cells display proliferative regeneration in intestinal epithelia upon cytotoxic damage and are highly sensitive to radiation-induced apoptosis ${ }^{24,25}$. The cells at position +4 within the intestinal crypt undergo continuous proliferation while retaining ${ }^{3} \mathrm{H}$-labeled DNA (hence, the cells are named label-retaining cells, or LRCs) and support the notion that " +4 " LRCs function as stem cells ${ }^{26}$. Bmi1, a chromatin silencing component, was identified as a marker for LRCs, and lineagetracing experiments revealed that $\mathrm{Bmi1} 1^{+} \mathrm{LRCs}$ are undifferentiated stem-like cells. Bmi1 ${ }^{+}$LRCs may either self-renew or clonally expand and differentiate into all cell types of the intestinal mucosa, including $\mathrm{Lgr}^{+}$columnar crypt base cells ${ }^{27,28}$. Unlike the turnover rate of Lgr $5^{+}$crypt base stem cells, that of $\mathrm{Bmi1}{ }^{+} \mathrm{LRCs}$ (situated just above the crypt base) is much slower, indicating that they are probably not the major stem cell type that functions in intestinal homeostasis ${ }^{27}$ and are proposed to function as reserve stem cells in response to tissue damage ${ }^{29}$. In addition to Bmi1, Hopx, Tert and Lrig1 are also markers of $\mathrm{LRCs}^{30-32}$. Although Lgr5 and Bmi1 are apparently markers of two distinct subpopulations of stem cells, there is an overlap between these markers with Bmil being strongly expressed by a subset of $\mathrm{Lgr}^{+} \mathrm{ISCs}^{19}$. Apart from LRCs, committed D $111^{+}$secretory progenitor cells located even further upwards from the crypt bottom also retain the ability to re-acquire stem cell 
functions and regenerate the stem cell compartment in response to tissue damage ${ }^{33}$. Although strong Wnt signaling and the paracrine context at the crypt base are essential components that regulate the maintenance of the ISC pool, more differentiated cells retain sufficient plasticity that allows them to revert to a stem cell-like behavior under stressful conditions ${ }^{29,30,34}$. Since genotoxic stress and other carcinogenic perturbations may affect the stem cell pool, they may also play a key role in the development of $\mathrm{CRC}^{34}$.

\section{Cancer stem cells and Wnt signaling in colorectal cancer}

CSCs are hypothesized to constitute a small fraction of the tumor tissue. In a role similar to that of ISCs in normal tissue, CSCs are suggested to give rise to progenitors that populate the majority of the tumor ${ }^{35}$. Two models describing the histogenesis of CRC have been proposed: the "top-down" and the "bottom-up" morphogenesis. The "top-down" model suggests that the more differentiated (luminal) cells re-acquire stem cell-like properties and produce aberrant crypt foci where tumors develop ${ }^{36}$. The "bottom-up" histogenesis suggests that stem cells residing at the crypt base expand and migrate upwards and constitute the tumor-initiating cells $^{37}$. In both models, Wnt signaling is considered an important regulator. According to the "top-down" theory, hyperactivation of $\beta$-catenin-TCF signaling drives differentiated epithelial cells into regaining pluripotency, thereby forming new, disregulated crypt-like structures that later turn into adenomas ${ }^{38}$. The increased frequency at which very early adenomatous polyps are observed at the top of colonic crypts (far removed from the stem cell compartment) has led researchers to suggest that neoplastic transformation in CRC is initiated from differentiated cells ${ }^{39}$. Other studies in transgenic mouse models for intestinal cancer have shown that differentiated epithelial cells can re-acquire stem cell-like properties upon the combined activation of Wnt and nuclear factor- $\kappa \mathrm{B}$ $(\mathrm{NF}-\kappa \mathrm{B})$ signaling, conferring tumor-initiating cell properties ${ }^{38}$. On the other hand, immunohistochemical studies of early sporadic colorectal adenomas have shown adenomatous lesions near the crypt base ${ }^{37}$. These lesions have increased proliferative activity with nuclear $\beta$-catenin localization while their corresponding surface epithelial cells maintain $\beta$-catenin in sub-membrane adherens junctions (not in the nucleus) ${ }^{37}$. Moreover, the conditional loss of APC in $\mathrm{Lgr}^{+}$colonic crypt base stem cells induced their rapid transformation into micro-adenomas, indicating that increased Wnt activity in the $\mathrm{Lgr}^{+}$stem cell compartment may trigger a tumor-initiating process ${ }^{40}$. Similarly, conditional activation of $\beta$-catenin in $\mathrm{Bmi}^{+} \mathrm{LRCs}$ led to an immediate generation of adenomas in the duodenum ${ }^{27}$. These studies support the "bottom up" histogenesis of CRC suggesting that excessive Wnt activation in the stem cell compartment is an essential step in neoplastic transformation. Chronic inflammation and other conditions that increase NF- $\kappa \mathrm{B}$ signaling support the notion that a dedifferentiation step can occur in intestinal epithelia, supporting CRC development by a "top down" histogenesis. Conversely, if stem cells at the crypt bottom acquire mutations that lead to activation of Wnt signaling, CRC may arise by the "bottom up" model.

One way or the other, the overriding importance of Wnt signaling in CRC development, as compared with other driving oncogenes in CRC, such as Kras and p53, was recently demonstrated by an effective, conditional suppression of APC by using small hairpin
RNA (shRNA) in transgenic mice ${ }^{41}$. The suppression of APC by this method resulted in intestinal and colon cancer development in mice. Restoration of APC expression in these tumors resulted in the reversal of tumorigenic lesions and the complete reconstitution of a normal stem cell compartment, even in mice harboring oncogenic Kras and $p 53^{41}$.

In CRC tissue, Wnt signaling (as gauged by nuclear $\beta$-catenin localization) is not homogenous, even though all CRC cells harbor an activating mutation in the Wnt pathway ${ }^{42}$. This observation, called "the $\beta$-catenin paradox", was first observed by immunohistochemical analyses of CRC tissue. Well-differentiated cells, located in the more central areas of the tumor, display mostly $\beta$-catenin associated with E-cadherin under the membrane, as in the normal intestinal epithelium, whereas tumor cells localized at the invasive front of the same tumor exhibit strong nuclear $\beta$-catenin staining ${ }^{43}$. These invasive edge-localized cells were shown to preferentially express Wnt target genes that confer invasivemetastatic capacity when expressed in human CRC cells ${ }^{44-46}$. Vermeulen et $a l .{ }^{47}$ investigated the role of Wnt signaling in the homeostasis of CSCs in human CRC: CSCs isolated from patients and cultured as spheroids displayed a heterogeneous level of Wnt signaling over a 100 -fold change. The $\mathrm{Wnt}^{\text {high }}$ cells formed more tumors in mice with fewer injected cells compared with Wnt ${ }^{\text {low }}$ cells. This heterogeneity in Wnt signaling was maintained in the tumors formed in mice that also expressed several ISC markers, including Lgr5 and Ascl2 ${ }^{47}$. The importance of Wnt signaling in the maintenance of the CSC pool and in driving CRC progression is also highlighted in a study in which conditional activation of the Wnt antagonist HoxA5 suppressed tumor growth and metastatic progression by repressing stemness properties ${ }^{15}$.

\section{Lgr5 as a Wnt-induced cancer stem cell marker}

Lgr5, a target gene of Wnt signaling, is a well-established ISC marker ${ }^{18}$. Studies involving mouse models of intestinal cancer have provided the initial evidence that $\mathrm{Lgr}^{+}$cells act as tumor-initiating cells, since activation of Wnt signaling (by conditional deletions of APC) in the $\mathrm{Lgr}^{+}$subpopulation of intestinal cells led to adenoma formation $^{40,48}$. Recent studies attempting to define an ISC gene signature in CRC tissue repeatedly detected Lgr5 as a key component in such signatures ${ }^{49-52}$. The presence of Lgr5 on the surface of cells is sufficient for successful isolation of the CSC fraction from CRC tissue, and similar to its role in the normal intestine, Lgr5 defines the undifferentiated stem cell state in CSCs. CRC cells with high Lgr5 expression had enhanced ability to clonally expand and give rise to colonies in vitro, whereas suppression of Lgr5 expression results in the loss of their ability to form colonies ${ }^{51}$. An ISC gene signature derived from EphB2 $2^{\text {high }}$ columnar crypt base cells was suggested as a powerful predicting tool of human CRC progression and disease relapse ${ }^{50}$. The EphB2 ${ }^{\text {high }}$ ISC signature had a significant overlap with a previously described Lgr5-ISC signature $^{19}$. Tumors with high levels of Lgr5-ISC signature genes were more aggressive and metastatic and also displayed an increased tendency to relapse in patients with $\mathrm{CRC}^{50}$. In an evaluation of 19 putative stem cell markers, Lgr5 was prevalently expressed in $74 \%$ of human CRC samples. Lgr5 and Ascl2 were significantly co-expressed with each other and with other genes from the list, supporting the hypothesis that adenocarcinomas are derived from Lgr $5^{+} / \mathrm{Ascl}^{+}{ }^{+}$crypt stem cells ${ }^{53}$. However, other studies have defined 
a non-Wnt-induced CSC gene list that does not include Lgr5 or other well-established Wnt-target genes. In a study on disease recurrence in CRC patients who went through curative surgery, a reverse correlation between Wnt-target genes (Lgr5, Ascl2, Axin2, $D k k 1$, and Apcdd1) levels and disease recurrence was found, suggesting that elevated expression of Wnt-target genes is associated with good prognosis ${ }^{54}$. Based on studies with CRC cell lines, these Wnt-target genes were silenced by $\mathrm{CpG}$ island methylation, and once methylation was inhibited, these cells lost their ability to generate colonies in vitro. These studies suggest that methylation of Wnttarget genes in CSCs is a strong predictor of CRC recurrence ${ }^{54}$.

\section{The involvement of Wnt-induced cancer stem cells in colorectal cancer metastasis}

According to the " $\beta$-catenin paradox", only cells at the invasive front of the tumor tissue display strong nuclear $\beta$-catenin localization. These cells apparently go through an epithelial-tomesenchymal transition (EMT), thus making them more motile and invasive, implying a role for the Wnt-induced CSCs in the propagation of metastasis. EMT has been suggested for some time as a key mechanism governing the generation of CSCs, especially as revealed by studies using breast cancer cell lines ${ }^{55}$. In CRC, the EMT program influences a variety of malignant phenotypes associated with metastasis, including the generation of CSCs, tumor budding, circulating tumor cells, and drug resistance ${ }^{56}$. The role of EMT in epithelial cancer, however, is still incompletely understood. Recent reports on lung and pancreatic cancer found that although EMT affects chemoresistance, it is not required for metastasis ${ }^{57,58}$. Since CSCs can both self-renew and differentiate, such cells can better adjust to the changes involved in the various stages of cancer metastasis ${ }^{59}$. The involvement of CSCs derived by activation of Wnt signaling in the later stages of cancer progression was suggested in a study showing that Lgr5 expression correlated with the malignant potential of CRC tumors and cell lines ${ }^{49}$. Tumors displaying increased levels of Lgr5 were of higher stage and were more invasive and formed more lymph node metastases ${ }^{49}$. With the increasing number of studies suggesting the involvement of CSCs in the propagation of metastasis, the hypothesis of "migrating cancer stem cells" (MCSCs) was put forward as the driving force leading to metastasis ${ }^{59,60}$. According to this model, the inherent plasticity of CSCs is employed during the advanced stages of cancer progression that require the acquisition of invasive properties and migration through the blood and lymph vessels to distant organs. Newly formed metastatic tumors were shown to have a high genomic and proteomic similarity to the primary tumors from which they were derived, suggesting that after colonization MCSCs revert to their initial phenotype ${ }^{61}$. A study comparing gene expression from primary CRC tissue and liver metastatic foci of the same patients found that the expression of Ascl2 (an ISC marker and Wnt target gene) is upregulated in the metastatic tumors together with several other Wnt-induced ISC markers, including Lgr5, EphB3, Ets2, and Sox $9^{61}$. Other ISC signature markers, such as $\operatorname{Smoc} 2^{19}$, were also found to play a role in the promotion of metastasis in human CRC cells ${ }^{62}$. Smoc2 expression was preferentially increased at the invasive edge of CRC tumors, and Smoc2 exclusively localized at the bottom of colonic crypts in the normal colonic epithelium ${ }^{63}$. Moreover, L1-induced metastatic CRC cell lines lost their metastatic potential when Smoc2 was silenced ${ }^{62}$.
Crosstalk between Wnt signaling and other pathways in "stemness" and colorectal cancer metastasis

Although Wnt/ $\beta$-catenin-TCF activation can directly influence the expression of "stemness" signature genes in CRC cells, such as Lgr5 and Ascl2, Wnt signaling often interacts with other pathways in triggering the acquisition of a stem cell-like behavior in CRC cells. Inflammation-related signaling has long been implied as a key regulator in Wnt- $\beta$-catenin-driven cancers, including $\mathrm{CRC}^{63}$. $\mathrm{NF}-\kappa \mathrm{B}$ signaling that regulates the pro-inflammatory cytokine response emerged as a key pathway in regulating the development of various cancers by being a potent driver of oncogenic signaling ${ }^{64}$. In view of the important role of Wnt signaling in the maintenance of the stem niche in intestinal tissue and its deregulation in CRC, it was of interest to determine whether Wnt and $\mathrm{NF}-\kappa \mathrm{B}$ signaling interact in promoting $\mathrm{CRC}$ progression. This was recently addressed in the context of the cell adhesion receptor L1 (or L1CAM), a $\beta$-catenin-TCF target gene in CRC cells ${ }^{45}$. L1 that is exclusively expressed in cells at the invasive edge of CRC tissue displaying nuclear $\beta$-catenin was found to activate NF- $\kappa$ B signaling by a mechanism involving the cytoskeletal protein ezrin ${ }^{65}$. L1 and ezrin, together with $\mathrm{I} \kappa \mathrm{B}$, form a complex that induces a more rapid degradation of I $\mathrm{KB}$, followed by nuclear translocation and activation of NF- $\kappa B$ target genes ${ }^{66}$. By blocking this L1-ezrin-NF- $\kappa B$ signaling, the acquisition of increased motility and liver metastasis by CRC cells was inhibited ${ }^{65}$. L1-induced NF- $\mathrm{\kappa B}$ activation leads to the expression of several ISC markers, including IGFBP2 ${ }^{66}$ and Smoc $2^{62}$. In another study, the loss of APC in CRC was shown to trigger the expression of a Rac1 GTPase, a member of the RACGEF family, via $\beta$-catenin-TCF-induced expression of the oncogenic transcription factor $\mathrm{c}-\mathrm{Myc}^{67,68}$. As in the case of $\mathrm{L1}^{66}$, the activation of Rac1 leads to enhanced NF- $\kappa \mathrm{B}$ signaling, resulting in the expansion of the $\mathrm{Lgr}^{+} \mathrm{CRC}$ stem cell compartment in an APCdeficient milieu ${ }^{68}$. Thus, activation of NF- $\mathrm{\kappa B}$ signaling in a $\mathrm{Wnt}^{\text {tigh }}$ context may potentiate tumor cells to acquire a stem cell-like phenotype $^{68}$. In addition, a constitutive activation of $\beta$-catenin signaling in differentiated intestinal epithelial cells of transgenic mice was shown to trigger the expansion of intestinal crypt cells and requires the activation of $N F-\kappa B$ signaling ${ }^{38}$. NF- $\kappa B$ was shown to directly bind to $\beta$-catenin and modulate its transcriptional activity, thereby affecting the expression of ISC signature genes ${ }^{38}$. Lastly, the inflammatory microenvironment displaying highly active $\mathrm{NF}-\kappa \mathrm{B}$ signaling was shown to lead to the acquisition of a stem cell-like behavior and neoplastic transformation ${ }^{69,70}$.

Bone morphogenetic protein (BMP) signaling, through the transcriptional co-activator SMAD4, also plays an important role in CRC tumorigenesis ${ }^{71}$. Mutations in the BMP receptor BMPRlA, or in $S M A D 4$, underlie the juvenile polyposis syndrome, a rare autosomal dominant trait with increased risk for $\mathrm{CRC}^{71}$. SMAD4 mutations were shown to account for the shift in CRC tumor phenotype from the large adenoma to the adenocarcinoma stage ${ }^{72,73}$. Wnt- $\beta$-catenin signaling was reported to be required for BMP4 expression in CRC tumors ${ }^{74,75}$, and the transcription factor GATA6 affects both BMP and Wnt signaling in CRC stem cells ${ }^{76}$. This is achieved by abrogating Wnt-triggered BMP4 expression in stem cells derived from colorectal adenoma that is apparently required for stem cell self-renewal in colon adenoma ${ }^{76}$. Thus, the modulation (by the Wnt pathway) of the strength of NF-KB signaling, or of BMP and additional signaling pathways, is an important 
determinant of CRC progression. The strength of BMP signaling and its downstream messengers, including SMAD4, and additional driver mutations of CRC, such as p53, may affect the outcome of Wnt signaling in CRC development ${ }^{77}$.

In addition to interacting with NF- $\mathrm{BB}$ and BMP signaling, the Wnt pathway affects other signaling molecules that are required for the acquisition and maintenance of the stem-like state in CRC cells. The $\beta$-catenin-TCF complex was shown to regulate the energy metabolism in CRC stem cells and to fuel the growth of CRC tumors by inducing the expression of the transcription factor PROX $1^{78,79}$. The cell adhesion receptor L1 (see above) induces the expression of the ISC marker Clusterin in CRC cells via STAT1 activation that is known to be stimulated by pro-inflammatory cytokines $^{80}$. The increased expression of the ISC marker Msi $1^{81}$, an RNA-binding protein and a $\beta$-catenin-TCF target gene, was linked to the elevated metastatic potential and poorer prognosis of $\mathrm{CRC}^{82,83}$. Msi1 can trigger the activation of Wnt and Notch signaling by a positive feedback regulation in ISCs, a regulatory loop recapitulated during CRC development ${ }^{84}$. The Msil homolog, Msi2 (also a $\beta$-catenin-TCF target gene), displays an increased expression in intestinal cancer and drives the proliferation of stem-like cells through inhibition of PTEN and by inducing the mTORC1 pathway ${ }^{85}$. Thus, together, these results suggest that the increase in Wnt signaling, even in more differentiated CRC cells, promotes the acquisition of a phenotype resembling that of ISCs by reconstituting a signaling environment that supports dedifferentiation.

\section{Conclusions}

A microenvironment enabling high Wnt signaling supports stem cell renewal at the base of the intestinal crypts of Lieberkühn and apparently leads to the acquisition of stem cell-like properties in cells at the invasive edge of CRC tissue. Although a link between "stemness" properties and metastasis was suggested by numerous studies, the existence of CSCs has been difficult to identify in clinical tumor samples ${ }^{35,86}$. A common concept in cancer development suggests that tumors arise from proliferation and survival of a clonal subpopulation of stem cells within the tumor. However, studies with CRC indicate that tumors may arise from several different parent cells, each contributing a distinct lesion and thus generating polyclonal tumors ${ }^{87}$. A polyclonal adenoma was described in an $\mathrm{XO} / \mathrm{XY}$ individual with familial adenomatous polyposis $(\mathrm{FAP})^{88}$. Polyclonal adenomas were also observed in mice with a chimeric loss in APC in the intestinal epithelium ${ }^{89}$. Conditional deletion of APC in stem cells labeled with a fluorescence reporter for Lgr5 triggered the development of adenomas from different cell clones within the intestinal tract ${ }^{48}$. Given the high plasticity of the intestinal and colonic crypt cells and their ability to readily revert to "stemness" upon stress, it is possible that the CSCs in CRC tissue originate from different lineages of parent cells. Although a stem cell hierarchy is supposed to exist in the CRC tissue, the high plasticity also means that the expression of ISC signature genes may be heterogeneous and thus cancer cells not originating from ISCs may also express ISC signature genes to some extent. Thus, CRC cells may express various stem cell markers without re-acquiring a full "stemness" potential. The contradictory reports regarding the association of Lgr5 with various stages of CRC progression ${ }^{49,50,53,54,90-92}$ could be explained by the heterogeneity among the cells of the $\mathrm{CRC}$ tissue, as related to the expression of stem cell markers. Our current understanding of stem markers comes from studies on Wnt target genes or of markers of the Bmi1+ LRCs that were identified as putative cells of the stem cell compartment. Given that some stem cell markers are not dependent on Wnt signaling, further studies are required to determine the functional relevance of the many genes identified as stem cell signature genes in both normal and CRC tissue. Determining their roles in CRC not only will provide a better understanding of their function in intestinal homeostasis but will provide novel markers for targeting CRC. Using expression profiles for multiple stem cell markers in tandem increases the successful prediction of prognosis and outcome in $\mathrm{CRC}^{50}$. Further studies of the stem cell niche and the molecules controlling self-renewal will provide a better definition of markers for the stem cell compartment. Current paradigms propose that treatments against cancer that fail to eradicate the CSC population will have little success in preventing future relapses of the disease. If correct, this hypothesis calls for additional research aiming to identify and understand the role of the subpopulations of CSCs in cancer development and for their more effective targeting.

\section{Abbreviations}

APC, adenomatous polyposis coli; BMP, bone morphogenetic protein; CK1, casein kinase 1; CRC, colorectal cancer; CSC, cancer stem cell; EMT, epithelial-to-mesenchymal transition; GSK3 $\beta$, glycogen synthase kinase $3 \beta$; ISC, intestinal stem cell; LEF, lymphoid enhancer factor; LRC, label-retaining cell; MCSC, migrating cancer stem cell; NF- $\kappa \mathrm{B}$, nuclear factor kappa light chain enhancer of B cells; TCF, T-cell factor.

\section{Competing interests}

The authors declare that they have no competing interests.

\section{Grant information}

Studies from the authors' laboratory were supported by grants from the Israel Science Foundation (ISF) and the Israel Cancer Research Fund (ICRF). 
1. Clevers H, Loh KM, Nusse R: Stem cell signaling. An integral program for tissue renewal and regeneration: Wnt signaling and stem cell control. Science. 2014; 346(6205): 1248012

PubMed Abstract | Publisher Full Text

2. Conacci-Sorrell M, Zhurinsky J, Ben-Ze'ev A: The cadherin-catenin adhesion system in signaling and cancer. J Clin Invest. 2002; 109(8): 987-91. PubMed Abstract | Publisher Full Text | Free Full Text

3. F Gross JC, Chaudhary V, Bartscherer K, et al.: Active Wnt proteins are secreted on exosomes. Nat Cell Biol. 2012; 14(10): 1036-45. PubMed Abstract | Publisher Full Text | F1000 Recommendation

4. F Alexandre C, Baena-Lopez A, Vincent JP: Patterning and growth control by membrane-tethered Wingless. Nature. 2014; 505(7482): 180-5. PubMed Abstract | Publisher Full Text | F1000 Recommendation

5. F Koo BK, Spit M, Jordens I, et al:: Tumour suppressor RNF43 is a stem-cell E3 ligase that induces endocytosis of Wnt receptors. Nature. 2012; 488(7413): 665-9.

PubMed Abstract | Publisher Full Text | F1000 Recommendation

6. $\mathrm{F}$ Hao $\mathrm{HX}, \mathrm{Xie} \mathrm{Y}$, Zhang $\mathrm{Y}$, et al:: ZNRF3 promotes Wnt receptor turnover in an R-spondin-sensitive manner. Nature. 2012; 485(7397): 195-200. PubMed Abstract | Publisher Full Text | F1000 Recommendation

7. Bienz M, Clevers H: Linking colorectal cancer to Wnt signaling. Cell. 2000; 103(2): 311-20.

PubMed Abstract | Publisher Full Text

8. Kinzler KW, Vogelstein B: Lessons from hereditary colorectal cancer. Cell. 1996; 87(2): 159-70.

PubMed Abstract | Publisher Full Text

9. Gavert N, Ben-Ze'ev A: beta-Catenin signaling in biological control and cancer. J Cell Biochem. 2007; 102(4): 820-8.

PubMed Abstract | Publisher Full Text

10. Marshman E, Booth C, Potten CS: The intestinal epithelial stem cell. Bioessays. 2002; 24(1): 91-8.

PubMed Abstract | Publisher Full Text

11. Gregorieff $A$, Clevers $H$ : Wnt signaling in the intestinal epithelium: from endoderm to cancer. Genes Dev. 2005; 19(8): 877-90.

PubMed Abstract | Publisher Full Text

12. Korinek V, Barker N, Moerer P, et al.: Depletion of epithelial stem-cell compartments in the small intestine of mice lacking Tcf-4. Nat Genet. 1998; 19(4): 379-83.

PubMed Abstract | Publisher Full Text

13. F Pinto D, Gregorieff A, Begthel $\mathrm{H}$, et al.: Canonical Wnt signals are essential for homeostasis of the intestinal epithelium. Genes Dev. 2003; 17(14): 1709-13. for homeostasis of the intestinal epithelium. Genes Dev. 2003; 17(14): 1709-13.
PubMed Abstract | Publisher Full Text | Free Full Text | F1000 Recommendation

14. Kuhnert F, Davis $\mathrm{CR}$, Wang $\mathrm{HT}$, et al.: Essential requirement for Wnt signaling in proliferation of adult small intestine and colon revealed by adenoviral expression of Dickkopf-1. Proc Natl Acad Sci U S A. 2004; 101(1): 266-71. PubMed Abstract | Publisher Full Text | Free Full Text

15. F Ordóñez-Morán P, Dafflon C, Imajo M, et al:: HOXA5 Counteracts Stem Cell Traits by Inhibiting Wnt Signaling in Colorectal Cancer. Cancer Cell. 2015; 28(6): 815-29.

PubMed Abstract | Publisher Full Text | F1000 Recommendation

16. Fevr $\mathrm{T}$, Robine $\mathrm{S}$, Louvard $\mathrm{D}$, et al:: Wnt/beta-catenin is essential for intestinal homeostasis and maintenance of intestinal stem cells. Mol Cell Biol. 2007; 27(21): 7551-9.

PubMed Abstract | Publisher Full Text | Free Full Text

17. $\mathrm{F}$ van Es JH, Haegebarth A, Kujala $\mathrm{P}$, et al:: A critical role for the Wnt effector Tcf4 in adult intestinal homeostatic self-renewal. Mol Cell Biol. 2012; 32(10): 1918-27.

PubMed Abstract | Publisher Full Text | Free Full Text | F1000 Recommendation

18. F Barker $\mathrm{N}$, van Es JH, Kuipers $\mathrm{J}$, et al:: Identification of stem cells in small intestine and colon by marker gene Lgr5. Nature. 2007; 449(7165): 1003-7. PubMed Abstract | Publisher Full Text | F1000 Recommendation

19. F Muñoz J, Stange DE, Schepers AG, et al.: The Lgr5 intestinal stem cell signature: robust expression of proposed quiescent ' +4 ' cell markers. $E M B O \mathrm{~J}$. 2012; 31(14): 3079-91.

PubMed Abstract | Publisher Full Text | Free Full Text | F1000 Recommendation

20. van der Flier LG, van Gijn ME, Hatzis P, et al:: Transcription factor achaete scutelike 2 controls intestinal stem cell fate. Cell. 2009; 136(5): 903-12. PubMed Abstract | Publisher Full Text

21. F Furuyama $\mathrm{K}$, Kawaguchi $\mathrm{Y}$, Akiyama $\mathrm{H}$, et al.: Continuous cell supply from a Sox9-expressing progenitor zone in adult liver, exocrine pancreas and intestine. Nat Genet. 2011; 43(1): 34-41.

PubMed Abstract | Publisher Full Text | F1000 Recommendation

22. F Ramalingam S, Daughtridge GW, Johnston MJ, et al.: Distinct levels of Sox9 expression mark colon epithelial stem cells that form colonoids in culture. Am J Physiol Gastrointest Liver Physiol. 2012; 302(1): G10-20. PubMed Abstract | Publisher Full Text | Free Full Text | F1000 Recommendation

23. Clevers H: The intestinal crypt, a prototype stem cell compartment. Cell. 2013;
154(2): 274-84

PubMed Abstract | Publisher Full Text

24. Potten CS, Booth C, Pritchard DM: The intestinal epithelial stem cell: the mucosal governor. Int J Exp Pathol. 1997; 78(4): 219-43.

PubMed Abstract | Publisher Full Text | Free Full Text

25. Potten CS: Stem cells in gastrointestinal epithelium: numbers, characteristics and death. Philos Trans R Soc Lond B Biol Sci. 1998; 353(1370): 821-30. PubMed Abstract | Publisher Full Text | Free Full Text

26. Potten CS, Owen G, Booth D: Intestinal stem cells protect their genome by selective segregation of template DNA strands. J Cell Sci. 2002; 115(Pt 11): 2381-8.

PubMed Abstract

27. Sangiorgi E, Capecchi MR: Bmi1 is expressed in vivo in intestinal stem cells. Nat Genet. 2008; 40(7): 915-20.

PubMed Abstract | Publisher Full Text | Free Full Text

28. $\mathrm{F}$ Yan KS, Chia LA, Li X, et al.: The intestinal stem cell markers Bmi1 and Lgr5 identify two functionally distinct populations. Proc Natl Acad Sci U S A 2012; 109(2): 466-71.

PubMed Abstract | Publisher Full Text | Free Full Text | F1000 Recommendation

29. F Buczacki SJ, Zecchini HI, Nicholson AM, et al:: Intestinal label-retaining cells are secretory precursors expressing Lgr5. Nature. 2013; 495(7439): 65-9. PubMed Abstract | Publisher Full Text | F1000 Recommendation

30. $\mathrm{F}$ Montgomery RK, Carlone DL, Richmond CA, et al:: Mouse telomerase reverse transcriptase (mTert) expression marks slowly cycling intestinal stem cells. Proc Natl Acad Sci U S A. 2011; 108(1): 179-84.

PubMed Abstract | Publisher Full Text | Free Full Text | F1000 Recommendation

31. $\mathrm{F}$ Powell AE, Wang $\mathrm{Y}$, Li $\mathrm{Y}$, et al.: The pan-ErbB negative regulator Lrig1 is an intestinal stem cell marker that functions as a tumor suppressor. Cell. 2012; 149(1): 146-58.

PubMed Abstract | Publisher Full Text | Free Full Text | F1000 Recommendation

32. $\mathrm{F}$ Takeda N, Jain R, LeBoeuf MR, et al:: Interconversion between intestinal stem cell populations in distinct niches. Science. 2011; 334(6061): 1420-4. PubMed Abstract | Publisher Full Text | Free Full Text | F1000 Recommendation

33. $\mathrm{F}$ van $\mathrm{Es} \mathrm{JH}$, Sato $\mathrm{T}$, van de Wetering $\mathrm{M}$, et al.: DII1+ secretory progenitor cells revert to stem cells upon crypt damage. Nat Cell Biol. 2012; 14(10): 1099-104. PubMed Abstract | Publisher Full Text | Free Full Text | F1000 Recommendation

34. Vermeulen L, Snippert $\mathrm{HJ}$ : Stem cell dynamics in homeostasis and cancer of the intestine. Nat Rev Cancer. 2014; 14(7): 468-80.

PubMed Abstract | Publisher Full Text

35. Gupta PB, Chaffer CL, Weinberg RA: Cancer stem cells: mirage or reality? Nat Med. 2009; 15(9): 1010-2.

PubMed Abstract | Publisher Full Text

36. Shih IM, Wang TL, Traverso G, et al.: Top-down morphogenesis of colorectal tumors. Proc Natl Acad Sci U S A. 2001; 98(5): 2640-5. PubMed Abstract | Publisher Full Text | Free Full Text

37. Preston SL, Wong WM, Chan AO, et al:: Bottom-up histogenesis of colorectal adenomas: origin in the monocryptal adenoma and initial expansion by crypt fission. Cancer Res. 2003; 63(13): 3819-25. PubMed Abstract

38. F Schwitalla S, Fingerle AA, Cammareri $P$, et al.: Intestinal tumorigenesis initiated by dedifferentiation and acquisition of stem-cell-like properties. Cell. 2013; 152(1-2): 25-38.

PubMed Abstract | Publisher Full Text | F1000 Recommendation

39. Cole JW, McKalen A: Studies on the morphogenesis of adenomatous polyps in the human colon. Cancer. 1963; 16(8): 998-1002. PubMed Abstract | Publisher Full Text

40. F Barker N, Ridgway RA, van Es JH, et al:: Crypt stem cells as the cells-of-origin of intestinal cancer. Nature. 2009; 457(7229): 608-11. PubMed Abstract | Publisher Full Text | F1000 Recommendation

41. F Dow LE, O'Rourke KP, Simon J, et al.: Apc Restoration Promotes Cellular Differentiation and Reestablishes Crypt Homeostasis in Colorectal Cancer. Cell. 2015; 161(7): 1539-52.

PubMed Abstract | Publisher Full Text | Free Full Text | F1000 Recommendation

42. Brabletz T, Jung A, Reu S, et al:: Variable beta-catenin expression in colorectal cancers indicates tumor progression driven by the tumor environment. ProC Natl Acad Sci U S A. 2001; 98(18): 10356-61.

PubMed Abstract | Publisher Full Text | Free Full Text

43. Brabletz $\mathrm{T}$, Jung $\mathrm{A}$, Hermann $\mathrm{K}$, et al:: Nuclear overexpression of the oncoprotein beta-catenin in colorectal cancer is localized predominantly at the invasion front. Pathol Res Pract. 1998; 194(10): 701-4. PubMed Abstract | Publisher Full Text

44. Jung $A$, Schrauder $M$, Oswald $U$, et al:: The invasion front of human colorectal adenocarcinomas shows co-localization of nuclear beta-catenin, cyclin D1, and $16^{\mathrm{INK} 4 \mathrm{~A}}$ and is a region of low proliferation. Am J Pathol. 2001; 159(5): 1613-7.

PubMed Abstract | Publisher Full Text | Free Full Text

45. Gavert N, Conacci-Sorrell M, Gast D, et al.: L1, a novel target of beta-catenin 
signaling, transforms cells and is expressed at the invasive front of colon cancers. J Cell Biol. 2005; 168(4): 633-42.

PubMed Abstract | Publisher Full Text | Free Full Text

46. Vignjevic D, Schoumacher M, Gavert N, et al.: Fascin, a novel target of betacatenin-TCF signaling, is expressed at the invasive front of human colon cancer. Cancer Res. 2007; 67(14): 6844-53.

PubMed Abstract | Publisher Full Text

47. F Vermeulen L, De Sousa E Melo F, van der Heijden M, et al:: Wnt activity defines colon cancer stem cells and is regulated by the microenvironment. Nat Cell Biol. 2010; 12(5): 468-76.

PubMed Abstract | Publisher Full Text | F1000 Recommendation

48. F Schepers AG, Snippert HJ, Stange DE, et al:: Lineage tracing reveals Lgr5+ stem cell activity in mouse intestinal adenomas. Science. 2012; 337(6095): 730-5. PubMed Abstract | Publisher Full Text | F1000 Recommendation

49. F Uchida H, Yamazaki K, Fukuma M, et al:: Overexpression of leucine-rich epeat-containing G protein-coupled receptor 5 in colorectal cancer. Cancer Sci. 2010; 101(7): 1731-7.

PubMed Abstract | Publisher Full Text | F1000 Recommendation

50. F Merlos-Suárez A, Barriga FM, Jung $\mathrm{P}$, et al: The intestinal stem cell signature identifies colorectal cancer stem cells and predicts disease relapse. Cell Stem Cell. 2011; 8(5): 511-24.

PubMed Abstract | Publisher Full Text | F1000 Recommendation

51. F Kemper K, Prasetyanti PR, De Lau W, et al:: Monoclonal antibodies against Lgr5 identify human colorectal cancer stem cells. Stem Cells. 2012; 30(11): 2378-86.

PubMed Abstract | Publisher Full Text | F1000 Recommendation

52. F Dalerba P, Kalisky T, Sahoo D, et al:: Single-cell dissection of transcriptional heterogeneity in human colon tumors. Nat Biotechnol. 2011; 29(12): 1120-7.

PubMed Abstract | Publisher Full Text | Free Full Text | F1000 Recommendation

53. F Ziskin JL, Dunlap D, Yaylaoglu M, et al:: In situ validation of an intestinal stem cell signature in colorectal cancer. Gut. 2013; 62(7): 1012-23. PubMed Abstract | Publisher Full Text | F1000 Recommendation

54. F De Sousa E Melo F, Colak S, Buikhuisen J, et al:: Methylation of cancerstem-cell-associated Wnt target genes predicts poor prognosis in colorectal cancer patients. Cell Stem Cell. 2011: 9(5): 476-85.

PubMed Abstract | Publisher Full Text | F1000 Recommendation

55. YeX, Weinberg RA: Epithelial-Mesenchymal Plasticity: A Central Regulator of Cancer Progression. Trends Cell Biol. 2015; 25(11): 675-86. PubMed Abstract | Publisher Full Text | Free Full Text

56. $\mathrm{Cao} \mathrm{H}, \mathrm{Xu} \mathrm{E}$, Liu $\mathrm{H}$, et al.: Epithelial-mesenchymal transition in colorectal cancer metastasis: A system review. Pathol Res Pract. 2015; 211(8): 557-69. PubMed Abstract | Publisher Full Text

57. $\mathrm{F}$ Zheng $\mathrm{X}$, Carstens JL, Kim J, et al:: Epithelial-to-mesenchymal transition is dispensable for metastasis but induces chemoresistance in pancreatic cancer. Nature 2015. 527(7579): 525-30.

PubMed Abstract | Publisher Full Text | F1000 Recommendation

58. F Fischer KR, Durrans A, Lee S, et al:: Epithelial-to-mesenchymal transition is not required for lung metastasis but contributes to chemoresistance. Nature. 2015; 527(7579): 472-6.

PubMed Abstract | Publisher Full Text | Free Full Text | F1000 Recommendation

59. Fodde $\mathrm{R}$, Brabletz $\mathrm{T}$ : Wnt/beta-catenin signaling in cancer stemness and malignant behavior. Curr Opin Cell Biol. 2007; 19(2): 150-8. PubMed Abstract | Publisher Full Text

60. Oskarsson T, Batlle E, Massagué J: Metastatic stem cells: sources, niches, and vital pathways. Cell Stem Cell. 2014; 14(3): 306-21. PubMed Abstract | Publisher Full Text | Free Full Text

61. F Stange DE, Engel F, Longerich $\mathrm{T}$, et al:: Expression of an ASCL2 related stem cell signature and IGF2 in colorectal cancer liver metastases with 11p15.5 gain. Gut. 2010; 59(9): 1236-44.

PubMed Abstract | Publisher Full Text | F1000 Recommendation

62. Shvab A, Haase G, Ben-Shmuel A, et al.: Induction of the intestinal stem cell signature gene SMOC-2 is required for L1-mediated colon cancer progression. Oncogene. 2016: 35(5): 549-57.

PubMed Abstract | Publisher Full Tex

63. Vaiopoulos AG, Athanasoula KC, Papavassiliou AG: NF-KB in colorectal cancer. J Mol Med (Berl). 2013; 91(9): 1029-37. PubMed Abstract | Publisher Full Tex

64. Karin M, Cao Y, Greten FR, et al:: NF-kappaB in cancer: from innocent bystander to major culprit. Nat Rev Cancer. 2002; 2(4): 301-10. PubMed Abstract | Publisher Full Tex

65. F Gavert N, Ben-Shmuel A, Lemmon V, et al:: Nuclear factor-kappaB signaling and ezrin are essential for L1-mediated metastasis of colon cancer cells. $J$ Cell Sci. 2010; 123(Pt 12): 2135-43.

PubMed Abstract | Publisher Full Text | Free Full Text | F1000 Recommendation

66. Ben-Shmuel A, Shvab A, Gavert N, et al.: Global analysis of L1-transcriptomes identified IGFBP-2 as a target of ezrin and NF-кB signaling that promotes colon cancer progression. Oncogene. 2013; 32(27): 3220-30.

PubMed Abstract | Publisher Full Text

67. F Athineos D, Sansom OJ: Myc heterozygosity attenuates the phenotypes of APC deficiency in the small intestine. Oncogene. 2010; 29(17): 2585-90. PubMed Abstract | Publisher Full Text | F1000 Recommendation

68. F Myant KB, Cammareri P, McGhee EJ, et al.: ROS production and NF-кB activation triggered by RAC1 facilitate WNT-driven intestinal stem cell proliferation and colorectal cancer initiation. Cell Stem Cell. 2013; 12(6): 761-73. PubMed Abstract | Publisher Full Text | Free Full Text | F1000 Recommendation

69. F Hanahan D, Weinberg RA: Hallmarks of cancer: the next generation. Cell. 2011; 144(5): 646-74.

PubMed Abstract | Publisher Full Text | F1000 Recommendation

70. Quante M, Varga J, Wang TC, et al:: The gastrointestinal tumo microenvironment. Gastroenterology. 2013; 145(1): 63-78. PubMed Abstract | Publisher Full Text | Free Full Text

71. Hardwick JC, Kodach LL, Offerhaus GJ, et al:: Bone morphogenetic protein signalling in colorectal cancer. Nat Rev Cancer. 2008; 8(10): 806-12. PubMed Abstract | Publisher Full Text

72. F Drost J, van Jaarsveld RH, Ponsioen B, et al.: Sequential cancer mutations in cultured human intestinal stem cells. Nature. 2015; 521(7550): 43-7. PubMed Abstract | Publisher Full Text | F1000 Recommendation

73. Grady WM, Markowitz SD: Genetic and epigenetic alterations in colon cancer. Annu Rev Genomics Hum Genet. 2002; 3: 101-28. PubMed Abstract | Publisher Full Text

74. Kim JS, Crooks H, Dracheva T, et al:: Oncogenic beta-catenin is required for bone morphogenetic protein 4 expression in human cancer cells. Cancer Res. 2002; 62(10): 2744-8. PubMed Abstract

75. F van de Wetering M, Sancho E, Verweij C, et al:: The beta-catenin/TCF-4 complex imposes a crypt progenitor phenotype on colorectal cancer cells. Cell. 2002; 111(2): 241-50. PubMed Abstract | Publisher Full Text | F1000 Recommendation

76. F Whissell G, Montagni E, Martinelli $P$, et al:: The transcription factor GATA6 enables self-renewal of colon adenoma stem cells by repressing BMP gene expression. Nat Cell Biol. 2014; 16(7): 695-707. PubMed Abstract | Publisher Full Text | F1000 Recommendation

77. F Voorneveld PW, Kodach LL, Jacobs RJ, et al:: The BMP pathway either enhances or inhibits the Wnt pathway depending on the SMAD4 and p53 status in CRC. Br J Cancer. 2015; 112(1): 122-30.

PubMed Abstract | Publisher Full Text | Free Full Text | F1000 Recommendation

78. F Ragusa S, Cheng J, Ivanov KI, et al:: PROX1 promotes metabolic adaptation and fuels outgrowth of Wnt ${ }^{(\text {high) }}$ metastatic colon cancer cells. Cell Rep. 2014; 8(6): 1957-73.

PubMed Abstract | Publisher Full Text | F1000 Recommendation

79. F Wiener Z, Högström J, Hyvönen V, et al:: Prox1 promotes expansion of the colorectal cancer stem cell population to fuel tumor growth and ischemia resistance. Cell Rep. 2014; 8(6): 1943-56.

PubMed Abstract | Publisher Full Text | F1000 Recommendation

80. Shapiro B, Tocci $\mathrm{P}$, Haase G, et al:: Clusterin, a gene enriched in intestinal stem cells, is required for L1-mediated colon cancer metastasis. Oncotarget. 2015; 6(33): 34389-401.

PubMed Abstract | Publisher Full Text | Free Full Text

81. Potten CS, Booth C, Tudor GL, et al:: Identification of a putative intestinal stem cell and early lineage marker; musashi-1. Differentiation. 2003; 71(1): 28-41. PubMed Abstract | Publisher Full Text

82. F Fan LF, Dong WG, Jiang CQ, et al:: Expression of putative stem cell genes Musashi-1 and beta1-integrin in human colorectal adenomas and adenocarcinomas. Int J Colorectal Dis. 2010; 25(1): 17-23. PubMed Abstract | Publisher Full Text | F1000 Recommendation

83. F Li D, Peng X, Yan D, et al.: Msi-1 is a predictor of survival and a nove therapeutic target in colon cancer. Ann Surg Oncol. 2011; 18(7): 2074-83. PubMed Abstract | Publisher Full Text | F1000 Recommendation

84. F Rezza A, Skah S, Roche C, et al:: The overexpression of the putative gut stem cell marker Musashi-1 induces tumorigenesis through Wnt and Notch activation. J Cell Sci. 2010; 123(Pt 19): 3256-65.

PubMed Abstract | Publisher Full Text | F1000 Recommendation

85. F Wang S, Li N, Yousefi M, et al.: Transformation of the intestinal epithelium by the MSI2 RNA-binding protein. Nat Commun. 2015; 6: 6517. PubMed Abstract | Publisher Full Text | Free Full Text | F1000 Recommendation

86. Takebe N, Ivy SP: Controversies in cancer stem cells: targeting embryonic signaling pathways. Clin Cancer Res. 2010; 16(12): 3106-12. PubMed Abstract | Publisher Full Text

87. Leedham SJ, Wright NA: Expansion of a mutated clone: from stem cell to tumour. J Clin Pathol. 2008; 61(2): 164-71.

PubMed Abstract | Publisher Full Tex 
Novelli MR, Williamson JA, Tomlinson IP, et al:: Polyclonal origin of colonic adenomas in an XO/XY patient with FAP. Science. 1996; 272(5265): 1187-90. PubMed Abstract | Publisher Full Text

89. Merritt AJ, Gould KA, Dove WF: Polyclonal structure of intestinal adenomas in

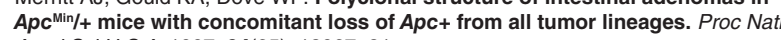
Acad Sci U S A. 1997; 94(25): 13927-31. PubMed Abstract | Publisher Full Text | Free Full Text

90. $\mathrm{F}$ He S, Zhou H, Zhu X, et al.: Expression of Lgr5, a marker of intestinal stem cells, in colorectal cancer and its clinicopathological significance. Biomed
Pharmacother. 2014; 68(5): 507-13.

PubMed Abstract | Publisher Full Text | F1000 Recommendation

91. F Takeda K, Kinoshita I, Shimizu Y, et al:: Expression of LGR5, an intestinal stem cell marker, during each stage of colorectal tumorigenesis. Anticancer Res. 2011; 31(1): 263-70.

PubMed Abstract | F1000 Recommendation

92. F Wu XS, Xi HQ, Chen L: Lgr5 is a potential marker of colorectal carcinoma stem cells that correlates with patient survival. World J Surg Oncol. 2012; 10: 244 PubMed Abstract | Publisher Full Text | Free Full Text | F1000 Recommendation 


\section{Open Peer Review}

\section{Current Peer Review Status:}

\section{Editorial Note on the Review Process}

Faculty Reviews are review articles written by the prestigious Members of Faculty Opinions. The articles are commissioned and peer reviewed before publication to ensure that the final, published version is comprehensive and accessible. The reviewers who approved the final version are listed with their names and affiliations.

\section{The reviewers who approved this article are:}

\section{Version 1}

\section{Hans Clevers}

Department of Developmental Biology and Stem Cell Research, Hubrecht Institute and University Medical Center, Utrecht, The Netherlands

Marc van de Wetering

Hubrecht Institute, Royal Netherlands Academy of Arts and Sciences, Utrecht,, The Netherlands Competing Interests: No competing interests were disclosed.

\section{Takeshi Sakurai}

Medical Innovation Center, Kyoto University Graduate School of Medicine, Kyoto, Japan

Competing Interests: No competing interests were disclosed.

\section{Jan Paul Medema}

Laboratory for Experimental Oncology and Radiobiology, Center for Experimental and Molecular Medicine, Academic Medical Center, Amsterdam, The Netherlands

Competing Interests: No competing interests were disclosed. 
The benefits of publishing with F1000Research:

- Your article is published within days, with no editorial bias

- You can publish traditional articles, null/negative results, case reports, data notes and more

- The peer review process is transparent and collaborative

- Your article is indexed in PubMed after passing peer review

- Dedicated customer support at every stage

For pre-submission enquiries, contact research@f1000.com 